\title{
"Asset operations of Ukrainian banks on the current stage of banking system development"
}

\begin{tabular}{|c|c|}
\hline AUTHORS & Iryna Tkachuk \\
\hline ARTICLE INFO & $\begin{array}{l}\text { Iryna Tkachuk (2017). Asset operations of Ukrainian banks on the current stage } \\
\text { of banking system development. Banks and Bank Systems, 12(1-1), 119-127. } \\
\text { doi:10.21511/bbs.12(1-1).2017.04 }\end{array}$ \\
\hline DOI & http://dx.doi.org/10.21511/bbs.12(1-1).2017.04 \\
\hline RELEASED ON & Wednesday, 26 April 2017 \\
\hline RECEIVED ON & Monday, 27 February 2017 \\
\hline ACCEPTED ON & Monday, 27 March 2017 \\
\hline LICENSE & $\begin{array}{l}(c) \text { EY-No } \\
\text { This work is licensed under a Creative Commons Attribution-NonCommercial } 4.0 \\
\text { International License }\end{array}$ \\
\hline JOURNAL & "Banks and Bank Systems" \\
\hline ISSN PRINT & $1816-7403$ \\
\hline ISSN ONLINE & $1991-7074$ \\
\hline PUBLISHER & LLC "Consulting Publishing Company "Business Perspectives" \\
\hline FOUNDER & LLC "Consulting Publishing Company "Business Perspectives" \\
\hline
\end{tabular}

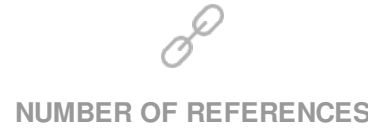

25

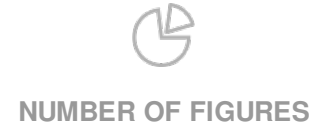

5
NUMBER OF TABLES

5

(C) The author(s) 2023. This publication is an open access article. 
Iryna Tkachuk (Ukraine)

\title{
Asset operations of Ukrainian banks on the current stage of banking system development
}

\begin{abstract}
The aim of the article is to characterize the real stage of realization of asset operations of the Ukrainian banks on the current stage of banking system development. For this aim the analysis of the Ukrainian banks activities within the period of 2011-2016 year is made. The official statistical data of the National Bank of Ukraine on asset operations of the Ukrainian banks and indicators of economic norms of banking were used. Thus, the current stage of credit operations realization by the banks of Ukraine, credit risk of the Ukrainian banks, and investment operations of the banks of Ukraine and the level of their investment risk were researched.

It has been elicited that the most numerous operations among all of the asset operations of the Ukrainian banks throughout the study period were credit operations, the volume of which, regardless of the decrease in 2013 and 2016 , had a clear tendency for increase. It has been calculated that within the study period the share of loans to business entities was continuously increasing, while the share of loans to private individuals was continuously decreasing, which led to the significant change in the proportions between these two groups of loans. It has been substantiated that the whole banking system was implementing the regulatory standards of credit risk set by the National Bank of Ukraine throughout the whole study period, which signifies that the credit activity of the Ukrainian banks was being conducted in the regulatory framework set by the authorities.

Investment operations of the Ukrainian banks in the period of 2011-2016 constituted the second largest group among all of the asset operations. It has been determined that their volume increased significantly within the study period and as a result their share in the general volume of asset operation of the Ukrainian banks increased as well, which signifies a certain diversification of asset operations of the Ukrainian banks.
\end{abstract}

Keywords: banks, banking system of Ukraine, economic norms of banking in Ukraine, asset operations.

JEL Classification: G21, G28.

Received on: $27^{\text {th }}$ of February, 2017.

Accepted on: $27^{\text {th }}$ of March, 2017.

\section{Introduction}

The modern tendencies of the development of the banking sector call for the implementation of measures to overcome the negative effects caused by globalization and international integration processes all around the world. In particular, this applies to the establishment of an adequate system of banking risks management. The basis of this system is targeted research of banking operations, the implementation of which is a source of banking risks. The risks associated with the implementation of asset banking operations are the essential ones among all of the banking risks in Ukraine and all around the world, as they are typically the most numerous within the banking system.

The financial potential of a bank is characterized by the amount and the structure of its non-current and current assets, which are derived from the available financial resources (own and borrowed). One of the most important principles of financial stability,

\footnotetext{
C) Iryna Tkachuk, 2017.

Iryna Tkachuk, Ph.D. in Economic, Assistant Professor of Finance and Credit Department, Yuriy Fedkovych Chernivtsi National University, Ukraine.

This is an Open Access article, distributed under the terms of the Creative Commons Attribution-NonCommercial 4.0 International license, which permits re-use, distribution, and reproduction, provided the materials aren't used for commercial purposes and the original work is properly cited.
}

solvency, and liquidity of the bank's activity is optimization of financial recourses allocation (in process of asset operations).

\section{Literature review}

Many well-known scientists have paid a lot of attention to the research of the banking system in general and the particular aspects of asset operations of the banks (including the issues about Ukrainian banking system).

Thus, Richard C. Porter (1996) divides the asset, which the bank can hold, into three general categories: cash assets, securities, and loans. He assumes that the portfolio of an actual bank will consist of a variety of assets in the range from cash to fairly long-term bonds. B. Fischer (1975) discusses general principles of choosing bank assets and liabilities, for deciding on when to make a loan and what interest rate to charge, for pricing funds transfer services, such as the handling of checks, for establishing compensating balance requirements, and for dealing with government regulation. K. J. Cohen and F. S. Hammer (1967) describe an important and complex analytical model developed by the Management science group Bankers Trust Company. H. T. Karcheva and O. Ya. Karcheva (2012) regard the issues of ensuring effective management of assets and liabilities in the context of minimizing liquidity risk and interest rate risk, increasing the financial stability of the bank. O. V. 
Lytvyniuk (2014; 2015) characterizes the theoretical foundations and components of bank assets and liability management within the controlling concept based on the interrelationship between the performance of the bank at various levels of management. He also specifies the methodological principles of forming bank assets and liabilities management system under the influence of the environment for enabling the study of management decisions at different levels. He justifies and defines the steps and strategies for asset and liability management, and offers methodical approach to determining the main stages in the development process of asset and liability management of the Ukrainian banks by analyzing the imbalance between the volumes of assets and liabilities. O. V. Schwarts $(2010 ; 2011 ; 2012 ; 2015)$ studies the essence of the management of assets and liabilities, researching the main goals of this process, and justifies the role of asset and liability management in the financial stability of the bank. He examines topical issues of integrated management of assets and liabilities of the bank. He pays considerable attention to the objectives and principles of the process of integral management of bank assets and liabilities, and indicates sources of information required for the effective asset and liability management. He suggests an advanced classification of management assets and liabilities methods from the standpoint of an integrated approach; isolating an additional classification feature - "management object", grouping management assets and liabilities methods, dividing them into basic specific risk management techniques and the methods of modeling the structure of the balance. K. M. Azizova and Yu. S. Tysiachna (2016) describe the process of the management of assets and liabilities as part of bank management system, while considering the management of assets and liabilities as a constant comparison and adjustment of parameters of banking institution balance in order to maintain profitability and minimize the unnecessary risks. O. H. Holovko and $\mathrm{H}$. M. Azarenkova $(2009 ; 2010 ; 2011 ; 2013)$ have formulated a scientific and methodological approach to assessing the financial stability of the bank's development, which takes into account both qualitative and quantitative characteristics of the bank through the use of methods of nonparametric statistics, which allows to determine the structural impact of individual components of the selected system of indicators on relatively stable functioning of the bank; they consider the appropriateness of the approach of assessing the financial stability of the bank on the basis of nonparametric methods of statistical analysis and reveal the qualitative component in evaluating the financial stability of the bank. O. H. Holovko and Ye. A. Olefir (2013), based on an analysis of loans and borrowed resources of the specific bank (PJSC "Ukrsotsbank") for the period of 2010-2012, reveal the methodological approach to determining the financial stability of the bank using nonparametric methods of statistical analysis. The team of authors led by V. V. Kovalenko (2015) determine the basic macroeconomic preconditions for the development of the bank credit activity; analyze the key organizational and functional aspects of the crediting activities of banks; justify the methods and tools for evaluating and minimizing credit risk; determine the scientific and methodological approaches to the system of credit risk management in banks.

Due to the rising banking risks, which are caused by the difficult economical and political situation, that takes place in Ukraine, investigation of the peculiarities of the asset operations process implementation are very important for stabilization of the banking system of Ukraine. Thus the methodological and scientific contribution of all above-mentioned authors is a base for our research.

The aim of the study. The aim of the study is to detect the peculiarities and tendencies of the asset operations of Ukrainian banks in the current stage of banking system development.

\section{Methodology}

2.1. Information basis. In order to carry out the research we have used:

- official statistical data of the National Bank of Ukraine;

- normative documents of the National Bank of Ukraine;

- scientific publications in this problem.

All of the processed data represent the period of 2011-2016.

2.2. Research methods. In order to achieve the objectives of the article we have used a set of general and specific research methods and techniques including the methods of deduction and abstraction identification; synthesis method, system approach (for the formation the tables which represent data about bank system functioning), and visualization (for graphic representation of the results) etc.

\section{Results and discussions}

Asset operations are the operations aimed at placement in the bank and use of private and raised funds for profit in the conditions of rational risk distribution for certain types of transactions and maintaining the necessary level of liquidity (Natsionalnyi bank Ukrainy, 2017a).

Asset operations are divided into credit, discount-credit and investment operations (Natsionalnyi bank Ukrainy, 2017a). They have a close interrelationship. These operations are the most profitable and risky at the same time. Therefore, banks are liable to maintain the op- 
timal structure of its assets and depending on the economic situation change it in favor of loans or investment. Today in Ukraine in the structure of active operations banks dominate lending operations. Up to date, credit operations predominate in the structure of asset operations of banks in Ukraine.
3.1. Current condition of credit operations conducted by the Ukrainian banks. Data on the total assets of the Ukrainian banks and, in particular, the volume of credit operations of domestic banks in the period of 2011-2016 are presented in Table 1.

Table 1. Credit operations in the structure of asset operations of the domestic banks in the period of 2011-2016., mln UAH*

\begin{tabular}{|c|c|c|c|c|c|c|}
\hline Name of indicator & 2011 & 2012 & 2013 & 2014 & 2015 & $2016^{\star *}$ \\
\hline Bank assets & 942088 & 1054280 & 1127192 & 1278095 & 1316852 & 1254385 \\
\hline Loans provided on their basis: & 755030 & 825320 & 815327 & 911402 & 1006358 & 965093 \\
\hline Loans to business entities & 508288 & 580907 & 609202 & 698777 & 802582 & 785918 \\
\hline Loans to individuals & 186540 & 174650 & 161775 & 167773 & 179040 & 152371 \\
\hline $\begin{array}{l}\text { The share of overdue loans in the } \\
\text { total sum of loans, } \%\end{array}$ & 11,2 & 9,6 & 8,9 & 7,7 & 13,5 & 22,1 \\
\hline $\begin{array}{l}1 \text { USD/ UAH (the nearest date, on } \\
\text { which that National bank of Ukraine } \\
\text { presents official currency course) }\end{array}$ & $\begin{array}{c}7.959 \\
\text { (January 6) }\end{array}$ & $\begin{array}{c}7.9898 \\
\text { (January 4) }\end{array}$ & $\begin{array}{c}7.993 \\
\text { (January 3) }\end{array}$ & $\begin{array}{c}7.993 \\
\text { (January 4) }\end{array}$ & $\begin{array}{c}15.7686 \\
\text { (January 1) }\end{array}$ & $\begin{array}{r}23.7837 \\
\text { (January 6) }\end{array}$ \\
\hline
\end{tabular}

* data, as of January 1 of each year.

** excluding insolvent banks.

As could be seen from Table 1, the volume of assets of the Ukrainian banks in the period of 20112016 was continuously rising (except for a slight reduction at the beginning of 2016).
As well as the volume of loans increased in total during this period. The dynamics of volumes of assets of domestic banks, as well as loans provided by them are graphically displayed in Fig. 1.

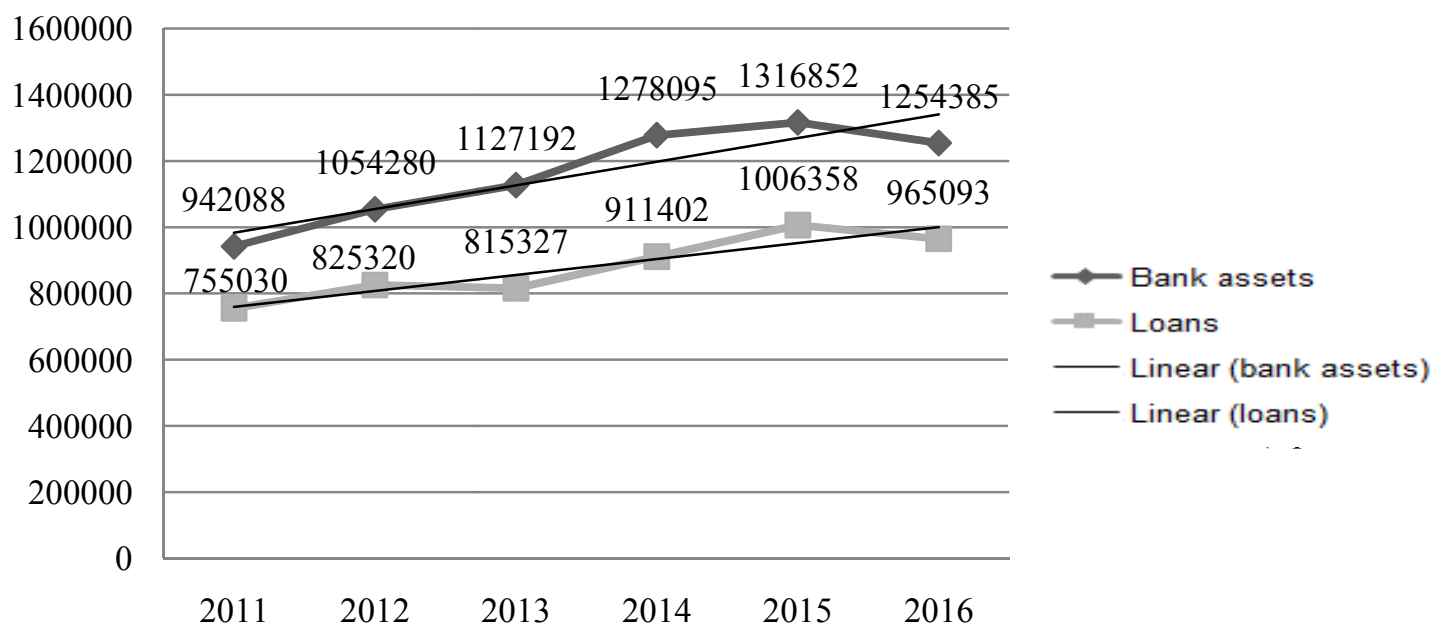

Fig. 1. Dynamics of volumes of assets of domestic banks of Ukraine as well as loans provided by them in the period, mln UAH ***

* data, as of January 1 of each year

** excluding insolvent banks

Despite the reduction in total assets of the banks in Ukraine as of January 1, 2016 (- 62,467 mln UAH compared with the previous year, which makes up $4.74 \%$ ) there is a tendency to increase in the study period, as shown by the line in Fig. 1 representing the tendency. The trend for rate of loans in the period is similar, showing a decrease as of 1 January 2013 and 1 January $2016(-9,993 \mathrm{mln}$ UAH (-1.21\%) and $-41,265$ mln UAH (-4.1\%), respectively).

It should be noted that the trend line for total assets of domestic banks and provided loans for 20112016 are almost parallel, indicating the significant scope of operations of domestic banks concerning the provision of loans in total assets of banks during the study period. Change of the share of loans in the structure of assets of the banks in Ukraine in 2011-2016 is represented in Fig. 2.

One can see from Fig. 2. that the percentage of loans in total volume of assets of the banks in Ukraine during 2011-2016 was located within the range of [71.3, 80.1] $\%$. The loans share was the biggest in 2011, but in the period of 2012-2014 it gradually declined, due to the minor crises in the global economy in 2012, which nevertheless are reflected in the domestic economy and influenced the creditworthiness of individuals and legal entities in Ukraine. 


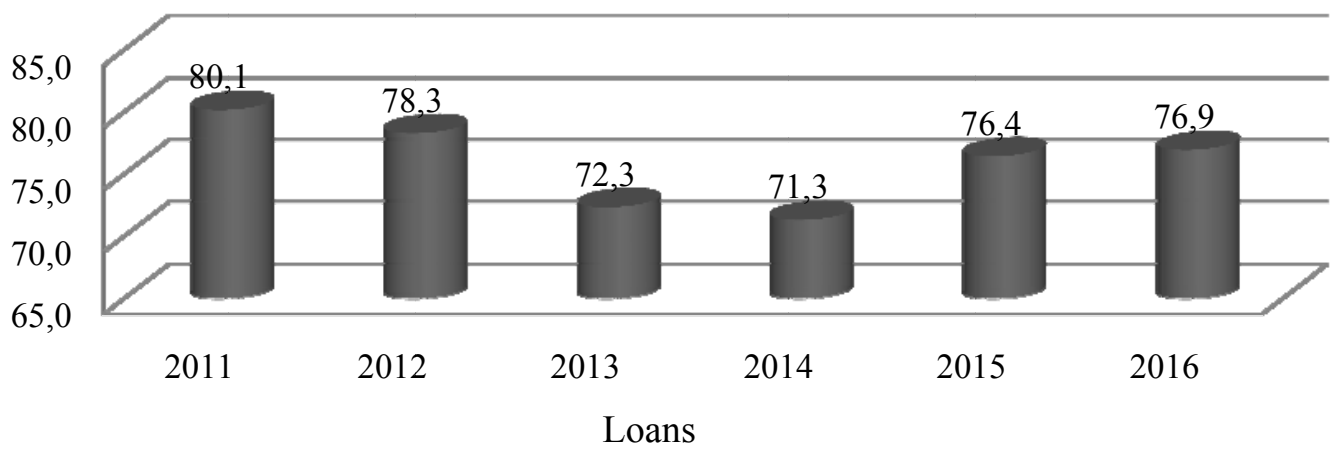

Fig. 2. Dynamics of the share of loans in the assets of the banks in Ukraine throughout the period of 2011-2016, \%*

*Source: compiled by the author on the basis of statistic information of National bank of Ukraine.

However, since 2015 the share of loans in the structure of total assets of the banks in Ukraine began to restore gradually. This situation demonstrates the substantial dependence of banks on the provided loans and their unwillingness to diversify the range of transactions significantly, even in spite of the unstable economic and political situation in the state, which significantly affects the volume of credit transactions.

The structure of the loans provided by the banks of Ukraine is represented in the Fig. 3.

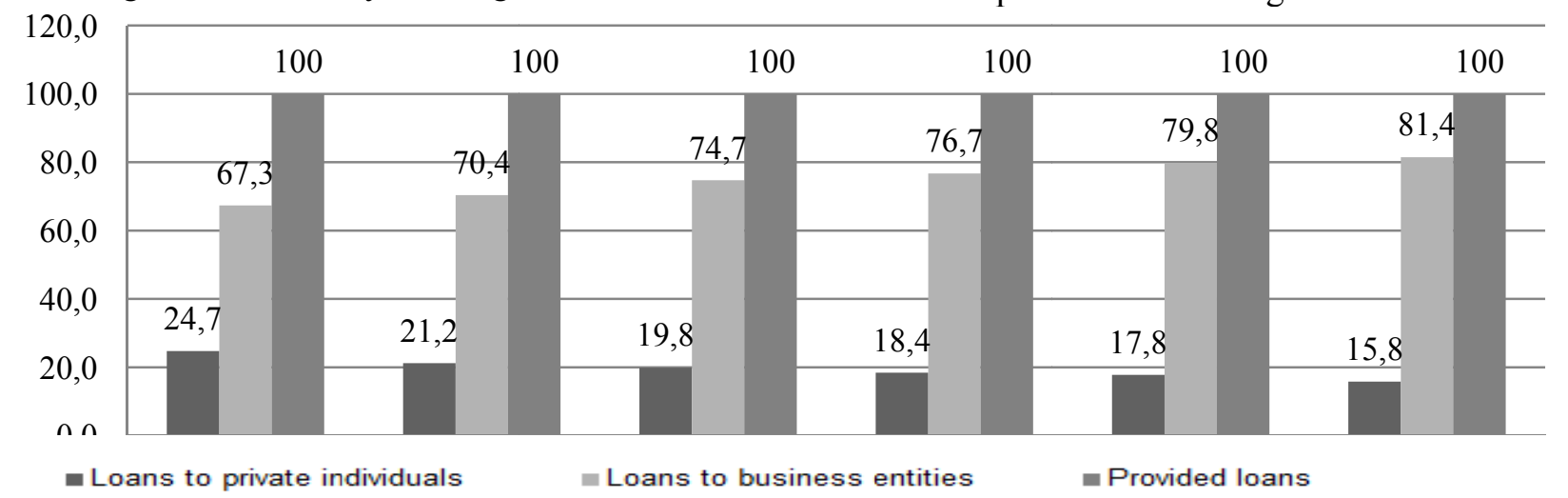

Fig. 3. Structure of the bank loans in Ukraine in the period of 2011-2016, \%

Fig. 3. demonstrates that the share of loans provided by the Ukrainian banks to business entities increased throughout the study period, while the share of loans granted to individuals declined continuously. Thus during this period, the share of loans to legal entities increased by 14.1 percentage points with the value of $67.3 \%$ as of January 1,2011 to a value of $81.4 \%$ as of January 1, 2016. A share of loans to private individuals decreased by 8.9 percentage points with the value of $24.7 \%$ as of January 1,2011 to a value of $15.8 \%$ as of January 1, 2016.

It should be noted that there is a constant change in the credit structure, which may indicate a deliberate gradual reduction in lending to the population and increase lending to businesses by the banks in Ukraine. On the one hand, this situation is understandable, given the high risks associated with lending to the population, and even positive, for the economy of Ukraine today needs strong support. However, on the other hand, a significant reduction in lending to households is the evidence of its insolvency and poverty and can lead to the decline of culture of using credit funds and to the downfall of consumer crediting.
3.2. Credit risk in the bank activity in Ukraine. Crediting as a process is accompanied by the emergence and existence of credit risk, which is an existing or potential risk to earnings and capital arising due to the inability of the party, which assumed the obligations, to fulfill the terms of any financial agreement with the bank or to fulfill its obligations in any other way (Natsionalnyi bank Ukrainy, 2017a).

In order to reduce and regulate credit risk the National Bank of Ukraine established regulatory standards of credit risk. Now the National Bank of Ukraine has set and calculates the follow in regulatory standards of credit risk (Natsionalnyi bank Ukrainy, 2015).

The maximum credit risk per counterparty (H7) regulation is set in order to limit the credit risk arising from the failure of individual contractors to fulfil their obligations. The size of the credit risk per counterparty is defined as the ratio of the amount of all claims of the bank to the counterparty and all offbalance sheet liabilities issued by the Bank to the counterparty (a group of related counterparties), to the bank's regulatory capital. 
The regulatory standard of large credit risks (H8) is set in order to limit the concentration of credit risk by individual counterparty or a group of related counterparties. Credit risk, which the bank took in the relation to one counterparty or a group of related counterparties is considered large if the total of all claims of the bank to the counterparty (a group of related counterparties) and all offbalance sheet liabilities granted by the bank to this counterparty or a group of related counterparties is $10 \%$ or more of the bank's regulatory capital. $\mathrm{H} 8$ is defined as a ratio of all large credit risks, the bank took in relation to all counterparties, taking into account all off-balance sheet liabilities issued by the bank for these counterparties to the bank's regulatory capital.

The regulatory standard of maximum credit risk on transactions with related to the bank parties (H9) is established in order to limit the risk of the operations with persons related to the bank, reduce the negative impact of transactions with individuals related of the bank on the activity of the bank. H9 ratio is defined as the ratio of the total of all claims of individuals related to the bank and the sum of all financial liabilities issued by the bank to individuals related to to the bank's regulatory capital.
Moreover, such regulatory standards as Maximum of the amount of the loan, guarantees and warranties to one insider and Maximum of total amount of loans, guarantees and warranties to insiders were calculated in the study period. These regulations are canceled now, however, they were calculated in the study period, and, thus, we studied their essence (Natsionalnyi bank Ukrainy, 2015).

Maximum amount of loans, guarantees and warranties to one insider (H9) was established in order to limit the risk arising from the transactions with insiders, which may lead to direct or indirect impact on the bank. H9 maximum is calculated as a ratio of all liabilities of the insider (a group of related insiders) to the bank and all off-balance liabilities issued by the bank to this insider, and the bank's statutory capital.

Maximum amount of loans, guarantees and warranties to insiders (H10) was established in order to limit the total sum of risks related to the insiders. H10 maximum is calculated as a ratio of all liabilities of all insiders to the bank and all off-balance liabilities issued by the bank to all insiders, and the bank's statutory capital;

The data on the performance of the credit risk regulative standards by the Ukrainian banks throughout the study period are represented by the Table 2 .

Table 2. Credit risk regulative standards of the National Bank of Ukraine in the period of 2011-2016*

\begin{tabular}{|l|l|c|c|c|c|c|c|}
\hline \multicolumn{1}{|c|}{ Regulative standard } & 2011 & 2012 & 2013 & 2014 & 2015 & 2016 \\
\hline H1 & Regulative capital (mln UAH) & 160897 & 178454 & 178908,9 & 204975,9 & 188948,9 & 129816,9 \\
\hline H7 & $\begin{array}{l}\text { Maximum credit risk per counterparty regulation } \\
\text { (under 25 \%) }\end{array}$ & 21.04 & 20.76 & 22.10 & 22.33 & 22.01 & 22.78 \\
\hline H8 & $\begin{array}{l}\text { Regulatory standard of large credit risks (under 8 } \\
\text { times of regulatory capital) }\end{array}$ & 161.20 & 164.46 & 172.91 & 172.05 & 250.04 & 364.14 \\
\hline H9 & $\begin{array}{l}\text { Regulatory standard of maximum credit risk on } \\
\text { transactions with related to the bank parties } \\
\text { (under25\%) }\end{array}$ & $\mathrm{x}$ & $\mathrm{x}$ & $\mathrm{x}$ & $\mathrm{X}$ & $\mathrm{X}$ & 31.19 \\
\hline $\mathrm{H} 9$ & $\begin{array}{l}\text { Maximum amount of loans. guarantees and } \\
\text { warranties to one insider regulation (under 5 \%) }\end{array}$ & 0.81 & 0.57 & 0.37 & 0.36 & 0.13 & $\mathrm{X}$ \\
\hline H10 & $\begin{array}{l}\text { Maximum amount of loans. guarantees and } \\
\text { warranties to insiders (under 30\%) }\end{array}$ & 2.25 & 2.51 & 2.41 & 1.63 & 1.37 & $\mathrm{X}$ \\
\hline
\end{tabular}

* data, as of January 1 of each year.

The conducted study showed that in 2011-2016 Ukrainian banks performed most of the credit risk regulations. This way, only Regulatory standard of maximum credit risk on transactions with related to the bank parties was not implemented on January 1, 2016 - it had the value of $31.19 \%$, which exceeded the standard value at $6.19 \%$. However, it was the first period in which this regulatory standard was calculated, and therefore it should be expected that in the future the average for the banking system ratio will correspond to the regulation.

Maximum credit risk per counterparty value is quite peculiar (H7) in 2011-2016 the banks did not exceed the regulatory standard value of $25 \%$, however, it should be noted that the average value within the banking system in the period was very high - over $20 \%$ (the lowest value of $20.76 \%$ being in 2012) and the average during the period was $21.84 \%$. Despite the implementation of regulation of the National Bank of Ukraine by the Ukrainian banks, this tendency indicates a significant dependence on the activities of individual counterparties, and, given the peculiarities of the banking sector of Ukraine, it also indicates a high probability of legalization of funds obtained by criminal means through the banking system.

\subsection{Investment operations of the Ukrainian} banks. Investments in securities are second popular investment option among active operations of the banks in Ukraine. 
Over 2011-2016 the volume of investments of the Ukrainian banks in securities increased by $137.97 \%$ (Table 3), while the volume of bank assets increased during the same period only by
$33.15 \%$. This growth led to significant changes in the share of investments in securities in total assets of the banks, namely the increase of $8.87 \%$ in 2011 and up to $15.85 \%$ in 2016.

Table 3. The analysis of bank operation with securities (investments insecurities) in the period of 2011-2016*

\begin{tabular}{|l|c|c|c|c|c|c|c|}
\hline \multicolumn{1}{|c|}{ Name of indicator } & 2011 & 2012 & 2013 & 2014 & 2015 & 2016 ** & $\begin{array}{c}\text { Deviation } \\
2011-2016, \%\end{array}$ \\
\hline Bank assets & 942088 & 1054280 & 1127192 & 1278095 & 1316852 & 1254385 & 33.15 \\
\hline Investments in securities & 83559 & 87719 & 96340 & 138287 & 168928 & 198841 & 137.97 \\
\hline Share of investments in securities & 8.87 & $8.32 \%$ & 8.55 & 10.82 & 12.83 & 15.85 & - \\
\hline
\end{tabular}

* data, as of January 1 of each year.

** excluding insolvent banks.

It should be noted that despite this significant increase in transactions of investments in securities by the Ukrainian banks, their share with the volume of loans provided in the period of 2011-2016 was disproportionate. The results of calculation demonstrate a small proportion of investments in securities in the structure of asset operations of banks compared to the credit operations - only $13 \%$ versus $87 \%$. However, it is important that the volume of transactions on investments in securities in this period increased significantly, while the volume of loans decreases just slightly (Fig. 4).

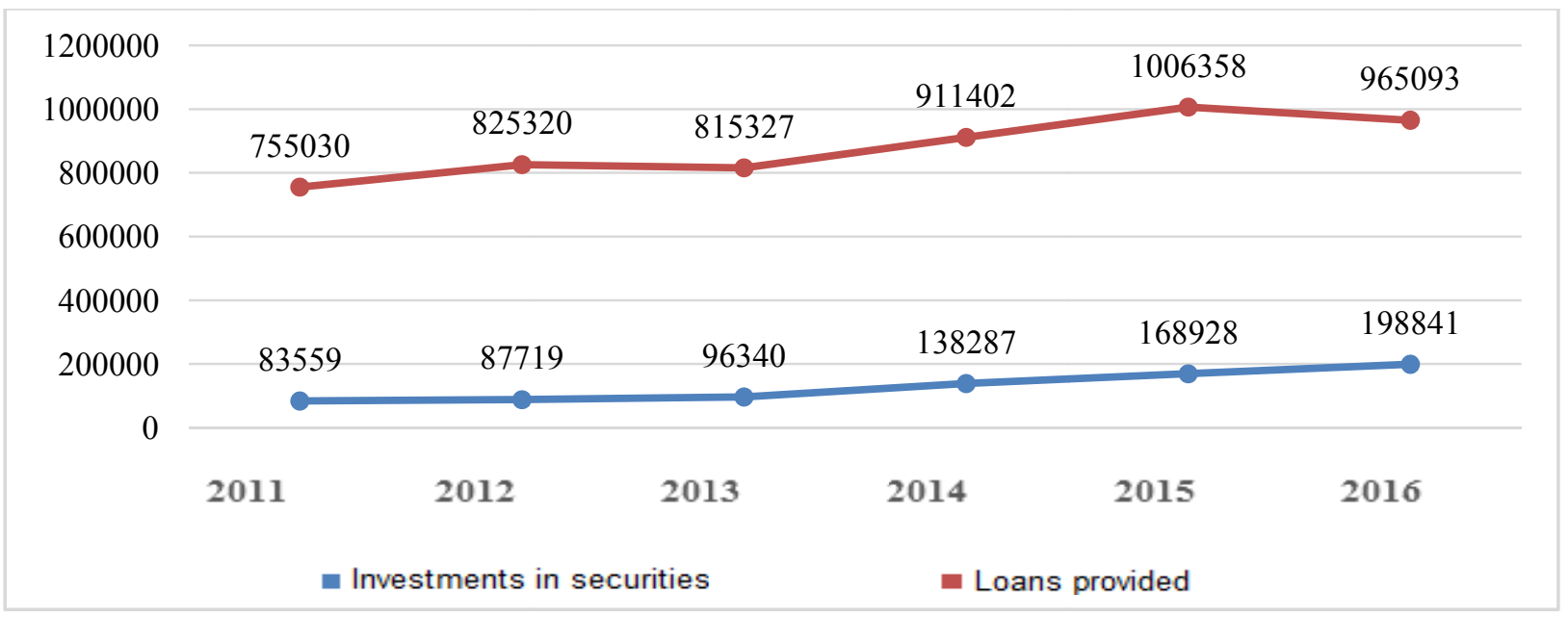

Fig. 4. The dynamics of asset operations of the Ukrainian banks (investments in securities and loans provided) in the period of 2011-2016 *

*Source: compiled by the author on the basis of statistic information of the National bank of Ukraine.

Such a small, at first glance, change in the volume Ukraine led to a major change in their correlation, of these two types of asset operations of the banks in which is demonstrated in Fig. 5.

2011

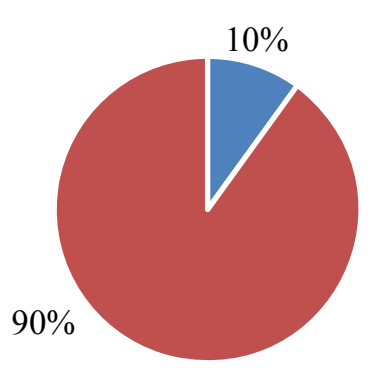

- Investments in securities

- Loans provided
2016

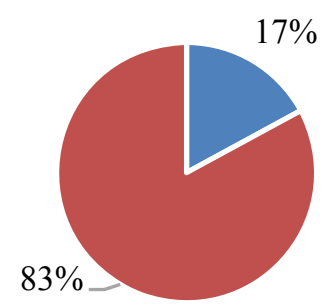

- Investments in securities

- Loans provided

Fig. 5. The comparison of the correlation of the loans provided and investments in securities as of January 1, 2011 and January 1, 2016 *

*Source: compiled by the author on the basis of statistic information of the National bank of Ukraine. 
3.4. Investment risk of the Ukrainian banks. Investing in securities of the banks is accompanied by investment risk.

Bank investment risk is a measure (degree) of uncertainty about the possibility of impairment of securities acquired by the bank, likelihood of not reaching the planned level of recoupment of new products, services, operations, technology, and also investment in real capital (Yepifanov, Vasylieva, Kozmenko, 2012; Yepifanov, Maslak, Salo, 2007).

To control the level of investment risk the National Bank of Ukraine sets regulatory standards of investment or so called 'investment caps'.

Investment caps are economical regulations set by the National Bank of Ukraine to maintain control of the investment activity by the banks, including of the direct investments. These regulations include H11 and H12 (Natsionalnyi bank Ukrainy, 2005).

The regulation of investment in securities by each institution (H11) is set to limit the risk associated with investing in shares, stocks, and investment certificates of a legal entity.

The regulation of investment $\mathrm{H} 11$ is defined as the ratio of the amount of funds invested in the purchase of shares (stocks) and investment certificates separately by each institution, to the bank's statutory capital. The regulatory value of $\mathrm{H} 11$ should not exceed $15 \%$.

The regulatory standard of the total amount of investments (H12) is set to limit the risks associated with the implementation of bank investment activity.

The H12 standard is defined as the ratio of the amount of money invested in the acquisition of shares (stocks) and investment certificates of any legal entity in the bank's statutory capital. Regulatory value of $\mathrm{H} 12$ should not exceed $60 \%$.

Data on the implementation of the investment regulatory standards of the National Bank of Ukraine by the Ukrainian banks in the period of 2011-2016 is presented in Table 4.

Table 4. Values of the investment regulatory standards of the National Bank of Ukraine on average within the banking system in the period of 2011-2016*

\begin{tabular}{|l|l|c|c|c|c|c|c|}
\hline \multicolumn{2}{|c|}{ Regulatory standard } & \multicolumn{5}{c|}{ Year } \\
\cline { 3 - 8 } & & 2011 & 2012 & 2013 & 2014 & 2015 & 2016 \\
\hline H11 & The regulation of investment in securities by each institution (under 15\%) & 0.05 & 0.06 & 0.09 & 0.04 & 0.01 & 0.002 \\
\hline H12 & The regulation of the total amount of investments (under \%) & 3.35 & 3.24 & 3.48 & 3.15 & 2.97 & 1.10 \\
\hline
\end{tabular}

* data, as of January 1 of each year.

** excluding insolvent banks.

Table 4 demonstrates that the Ukrainian banks always implemented the investment regulations of the National Bank of Ukraine in the given period. It should be noted that the implementations of the regulatory standards of $\mathrm{H} 11$ and $\mathrm{H} 12$ is not so much the result of the policy of the banks to implement the standard, but rather the result of the minor investment activity of the banks.

Another tool that the National Bank of Ukraine uses to reduce the risk on asset operations is asset reserving or asset provision. Accordingly, asset provisions for losses on asset operations are the reserves for possible losses on asset operations, which have a probability of occurrence. The amount of such reserves is determined as part of the cost of adversely classified assets, which the bank can, with some degree of certainty, based on previous experience, considered lost and thus relates to the expenses of its activities. In terms of accounting asset provisions are contractual regulatory account, which reduces the accounting value of assets. Provisions for losses on asset operations are not included in the bank's capital. They consist of provisions for credit risk, provisions for accrued income, provisions for receivables and reserves for correspondent accounts (Natsionalnyi bank Ukrainy, 2017a).
In the study period the Ukrainian banks made significant provisions for asset operations (Table 5), the volume of which increased significantly: 172,464 million UAH, which in relative terms was $115.87 \%$. This increase was the result of increasing asset operations of the banks in Ukraine.

Table 5. Asset operations provisions of the Ukrainian banks in the period of 2011-2016*

\begin{tabular}{|l|c|c|c|c|c|c|}
\hline & 2011 & 2012 & 2013 & 2014 & 2015 & $2016^{* *}$ \\
\hline $\begin{array}{l}\text { Provisions on asset } \\
\text { operations (taking into } \\
\text { account the provisions for } \\
\text { transactions that are }\end{array}$ & 148839 & 157907 & 141319 & 131252 & 204931 & 321303 \\
$\begin{array}{l}\text { accounted for off-balance } \\
\text { sheet) }\end{array}$ & & & & & & \\
\hline
\end{tabular}

* data, as of January 1 of each year.

** excluding insolvent banks.

Therefore, investment operations is the second largest among the active transactions carried out by the banks in Ukraine. Their volume increased significantly over the period 2011-2016, which led to an increase in their share of total assets of the banks in Ukraine and to a significant change in the ratio of loans provided and investments in securities. 


\section{Conclusions}

The asset operations of banks take important place in their work as they determine the level of the activities risks, profitability etc. The credit and investment operations are the most popular kinds of asset operations among the Ukrainian banks. Crediting remains the most popular among the asset operations of the banks in Ukraine. Its structure is dominated by loans provided for legal entities, the share of which has increased significantly over the period, while the share of loans to private individuals has decreased significantly. To control the level of credit risk the National Bank of Ukraine sets regulatory standards of credit risk that were implemented by the banks of Ukraine during the whole study period.
Investment operations take the second place among asset operations carried out by the banks in Ukraine. Their volume increased significantly over the period of 2011-2016, which led to an increase in their share of total assets of the banks in Ukraine and to a significant change in the ratio of loans and investments in securities. Reduction of the share of crediting operations and the increase of the share of operations with investment in securities in the study period are quite positive, as it is evidence of some diversification of asset operations of the banks in Ukraine, further reduction of credit risk and the movement towards the reduction of imbalances in the structure of asset operations.

\section{References}

1. Azarenkova, H. M. (2009). Uzahalnenyi pidkhid schodo vyznachennia otsinky finansovoi stabilnosti rozvytku banku. Visnyk NBU, 9, 18-21.

2. Azarenkova, H. M., Holovko, O. H., and Smirnov, V. V. (2011). Finansova stabilnist rozvytku bankiv: monohrafiia. K.: UABS NBU, 191.

3. Azarenkova, H., Holovko, O., and Trydid, O. (2013). Improvement of Assessment of Financial Stability of the Bank. Global and regional challenges of the 21st century economy. Cracow: Cracow university of economics, 445-453.

4. Azizova, K. M., Tysiachna, Yu. S. (2016). Upravlinnia aktyvamy i pasyvamy banku: sutnist ta metodychni pidkhody. Ekonomichnyi prostir, 107, 9-27.

5. Cohen, K. J., and Hammer, F. S. (1967). Linear programming and Optimal Bank Asset Management Decisions. Journal of Finance, 147-168.

6. Fischer, B. (1975). Banks Funds Management in an Efficient Market. Journal of Financial Economics, 2, 323-339.

7. Holovko, O. P. (2011). Finansova stabilnist rozvytku bankiv. DVNA "Ukrayinska akademiia bankivskoyi spravy Natsionalnoho banku Ukrainy", 179.

8. Holovko, O., and Olefir, Ie. (2013). Uzahalnena otsinka finansovoi stabilnosti banku. Retrieved from http://www.irbis-nbuv.gov.ua/cgibin/irbis nbuv/cgiirbis 64.exe?I21DBN=LINK\&P21DBN=UJRN\&Z21ID=\&S21REF=10\&S21CNR=20\&S21STN=1 $\& S 21 F M T=A S P \_m e t a \& C 21 C O M=S \& 2 \_S 21 P 03=F I L A=\& 2 \_S 21 S T R=V U b s N b U \_2013 \_3 \_32$ (24 March, 2017).

9. Karcheva, H. T., and Karcheva, O. Ia. (2012). Efektyvne upravlinnia aktyvamy i pasyvamy-neobkhidna umova finansovoi stiikosti banku. Retrieved from: http://nbuv.gov.ua/UJRN/NvChdieu_2012_1_40 (24 March, 2017).

10. Kovalenko, V. V. (2015). Kredytna diialnist bankiv Ukrayiny: problemy ta perspektyvy rozvytku: monohrafiia. Odesa: Atlant, 217.

11. Kozmenko, S., and Plastun, S. (2016). The viability of asset price channel implementation to the monetary transmission mechanism of Ukraine. Investment Management and Financial Innovations, 13(4), 58-67. Retrieved from $\mathrm{http} / / /$ businessperspectives.org/journals/investment-management-and-financial-innovations/issue-102/theviability-of-asset-price-channel-implementation-to-the-monetary-transmission-mechanism-of-ukraine

12. Lytvyniuk, A. V. (2014). Metodicheskie podkhody k opredeleniiu osnovnykh etapov razvitiia protsesov upravleniia aktivami i passivami bankovskikh uchrezhdenii Ukrainy. Retrieved from http://molodyvcheny.in.ua/files/journal/2014/7/61.pdf (24 March, 2017).

13. Lytvyniuk, O. (2015). Formuvannia systemy upravlinnia aktyvamy ta pasyvamy bankiv. Odesa: Odeskyi natsionalnyi ekonomichnyi universytet, 179.

14. Muradova, L. (2014). Important issues of increasing the active operations profitability of commercials banks. Retrieved from: http://advancedscience.org/2014/12/065-067.pdf (24 March, 2017).

15. Natsionalnyi bank Ukrainy. (2017a). Aktyvni operatsii. Retrieved from https://bank.gov.ua/control/uk/publish/article?art_id=123115 (24 March, 2017).

16. Natsionalnyi bank Ukrainy (2017b). Pokaznyky bankivskoi diialnosti. Retrieved from https://bank.gov.ua/control/uk/publish/article?art_id=34661442 (24 March, 2017).

17. Natsionalnyi bank Ukrainy. (2015). Pro zatverdzhennia zmin do Instruktsii pro poriadok rehuliuvannia diialnosti bankiv v Ukraini. Retrieved from: http://zakon5.rada.gov.ua/laws/show/v0312500-15 (24 March, 2017).

18. Porter, R. (1996). A Model of Bank Portfolio Selection. Yale Economic Essays (Fall), 1, 323-359.

19. Shwarts, O. V. (2010). GAP-menedzhment iak stratehiia upravlinnia aktyvamy i pasyvamy banku. Finansovokredytnyi mekhanizm aktyvizatsii investytsiinoho protsesu. Kyiv: KNEU, 484-486.

20. Shwarts, O. V. (2010). Intehrovane upravlinnia aktyvamy i pasyvamy iak filosofiia upravlinnia suchasnym bankom Kyiv: Visnyk KEF KNEU imeni Vadyma Hetmana, 1, 34-38. 
21. Shwarts, O. V. (2011). Udoskonalennia instrumentu upravlinnia aktyvamy i pasyvamy banku v umovakh finansovoi nestabilnosti. Svit finansiv, 4, 33-39.

22. Shwarts, O. V. (2012). Upravlinnia aktyvamy i pasyvamy banku. Kyiv: DVNZ "Kyivskii natsionalnyi ekonomichnyi universytet imeni Vadyma Hetmana", 214.

23. Shwarts, O. V. (2015). Upravlinnia aktyvamy i pasyvamy banku iak faktor zabezpechennia finansovoi stiikosti. Finansovyi prostir, 2(18), 146-150.

24. Yepifanov, A. O., Maslak, N. H., and Salo, I. V. (2007). Operatsii komertsiinykh bankiv. Sumy: Universytetska knyha, 523.

25. Yepifanov, A. O., Vasylieva, T. A., and Kozmenko, S. M. (2012). Upravlinnia ryzykamy bazovykh bankivskykh operatsii. Sumy: DVNZ "UABS NBU”, 283. 